\title{
Nutrient Potential and Economic Benefit of Varies Coleoptera (Grub Worm): Implication for Food Security
}

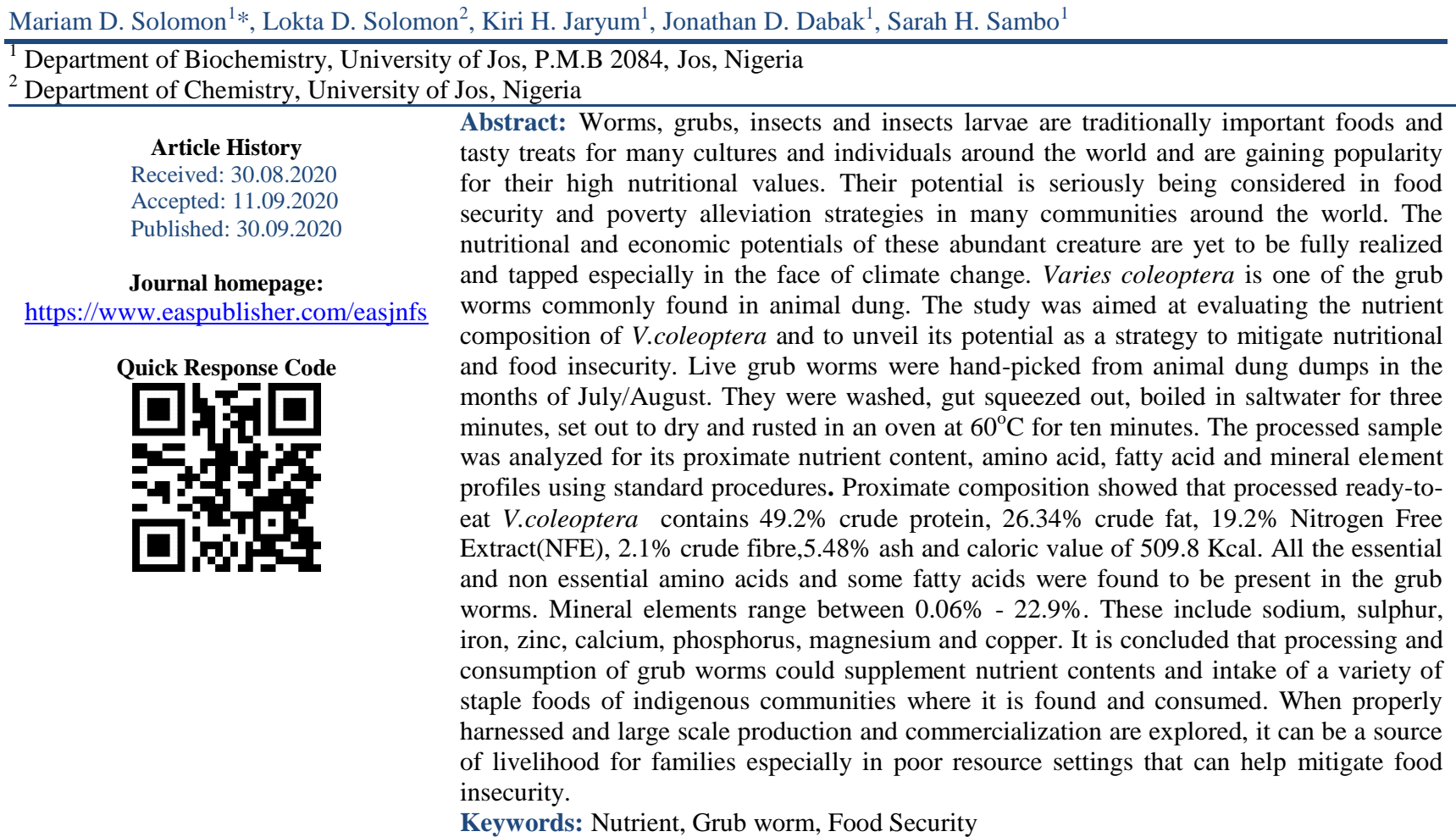
Copyright (C) 2020 The Author(s): This is an open-access article distributed under the terms of the Creative Commons Attribution 4.0 International License (CC BY-NC 4.0) which permits unrestricted use, distribution, and reproduction in any medium for non-commercial use provided the original author and source are credited.

\section{INTRODUCTION}

The need to feed a growing global population inevitably places continuous pressure on plant and animal food sources, which contribute to the degradation of natural resources (FAO 2009a). This is further compounded by global warming, climate change and recently, global pandemic and Lockdowns. It is estimated that by 2050, the world population will hit nine billion people, which would lead to reduced available farmland and increased additional need for food (Kourimskaa, L., \& Adamkovab, A. 2016). This will continue to pose challenge to food and nutrient security, poverty, malnutrition and disease burden in many countries of the world especially the underdeveloped and developing ones.

Over the years, FAO has focused activities on improving food and nutritional security that will provide more ecologically sound food and environmentally sustainable food system, and recommended that edible insects fit comfortably within this and, by extension, ought to be considered prime candidates as food staples and supplements, as well as more generally for their role in sustainable diets (FAO 2009b).

The great diversity of insects, worms and caterpillars that abound in many regions, climates and seasons of the world, and their rich nutrient composition can be harnessed to mitigate the challenges pose by climate change, food and nutritional insecurity, poverty and disease burden especially in poor-resource households and communities.

Already, eating of insects, worms and caterpillars is common and a popular delicacy in Africa, Asia and Latin America, where it is estimated that insects form about 5-10\% of protein consumed (FAO 2013). Small scale Processing and selling of this large 
group and popular biodiversity is a source of livelihood for families in many poor-resource settings (Solomon, M., \& Prisca, N. 2012; Finke, M.D., \& Oonincx, D.D. 2014; Van Huis, A. et al., 2013;\& Rumpold, B. A., \& Schlüter, O. K. 2013 ).

The nutritional value of edible insects is very diverse and changes according to the preparation and processing before consumption (Finke, M.D., \& Oonincx, D.D. 2014; Van Huis, A. et al., 2013). Edible insects are good sources of energy, protein and fat, can meet the amino acid, mono and polyunsaturated fatty acids requirements, are rich in trace mineral elements and vitamins [4,9]. They contain a significant amount of fibre mainly chitin, a prebiotic fiber that is basically nutrients for probiotic gut bacteria. Many edible insects and worms are very high in antioxidants. Crickets, grasshoppers and silkworms have been reported to have over three times the antioxidants as orange juice (Van Huis, A. et al., 2013).

The nutritional value and benefits as well as economic benefits of a variety of worms and grubs in different parts of the world have been reported (Elemo, B. O. et al., 2011; Okpala B. 2016; \& Nirmala, I. R., \& Pramono, M. S. 2017). Witchetty grubs, are an ideal survival food, being rich in protein ( $15 \%$ by weight), fat (20\%) and energy ( 1170 kilojoules per 100 grams). Witchetty grubs are a publicized food source for Australian Aborigines and valuable sources of vitamin B1 and the essential minerals potassium, magnesium

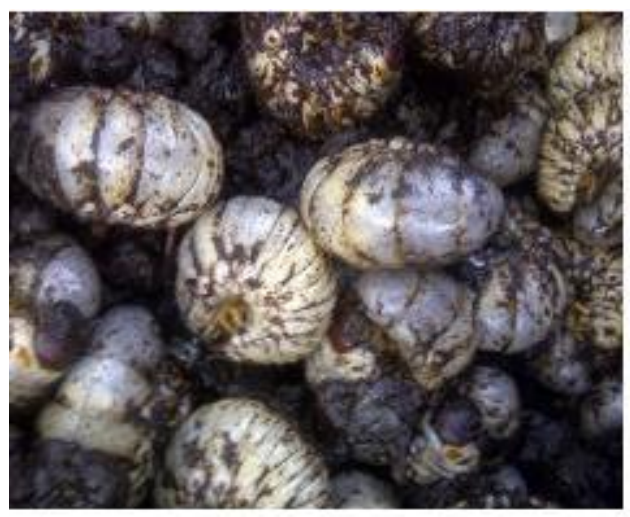

Figure 1: Live Grub Worms

\section{Proximate Analysis}

The proximate composition (crude protein, fibre,lipids, Nitogen Free Extract(NFE), moisture content and ash) of grub worms were analyzed using the standard procedures of AOAC (2015) [14]. Amino acid profile of the protein of grub worms was determined using the Technicon Analyzer (TSM-1), fatty acid profile was analyzed using Gas Chromatography while mineral content was anlyzed using Hitachi 180-80 atomic absorption spectrophotometer. Analysis were carried out in triplicate, results expressed as mean + SEM. and zinc (Forbes-Ewan, C. 2013; \& Yen, A. et al., 2018). White Grub worm is the larval stage of adult beetles commonly referred to as May beetles or June bugs. They are "C"-shaped, up to 1 inch long, with cream-colored bodies and brown head. They are frequently encountered when tilling garden soil or by sifting through soil underneath animal or grass dungs, therefore easy to find for those who consume worms on a regular basis and as livelihood or for medicinal purposes (Alhassan, A. J. et al., 2009). The aim of this work was to explore the nutrient and economic benefits of grub worms picked from animal dung sites in Jos metropolis, Nigeria, as possible strategy for mitigating food insecurity.

\section{Materials and Methods Collection and Preparation of Grub Worms}

Matured larvae (grub worms) of V.coleoptera were hand-picked from heaps of animal dungs in some cattle rearing communities in Jos Plateau State, Nigeria between the months of July and August.

The worms were washed with water, gut contents (feaces) were squeezed out from the cut posterior end and washed again with water. It was then boiled in slightly salted water for 5 minutes, set out to dry and then roasted in an oven at $60^{\circ} \mathrm{C}$ for 10 minutes. The dry worms were stored in desiccator until required for analysis.

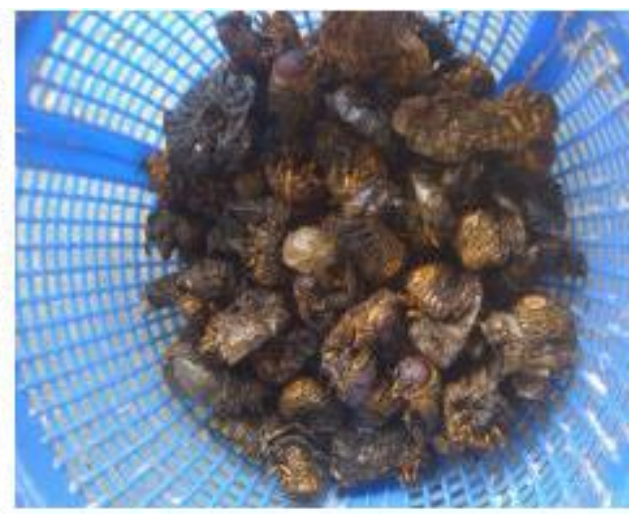

Figure 2: Processed Grub Worms

\section{RESUlTS}

The nutritional value of an edible food is determined by its nutrient content and nutrient value. The proximate composition of the grub worms is presented in table 1 . It shows that $49.2 \%$ dry weight of worm consists of crude protein followed by crude fat (26.3\%), NFE (19.2\%), moisture (7.1\%) and low crude fibre $(2.1 \%)$. Energy value was estimated to be $509.8 \mathrm{Kcal}$.The protein content was found to be higher than value reported in a similar work by Alhassan et al., (2009). 
The biological value of a Protein is partly determined by its Amino acid profile. As shown in table 2. The crude protein of grub worm contains both essential and non essential amino acids in appreciable amounts which range between 1.5 and $14.3 \mathrm{~g} / 100 \mathrm{~g}$ protein. Histidine $(1.5 \mathrm{~g} / 100 \mathrm{~g}$ protein) and Tryptophan $(1.7 \mathrm{~g} / 100 \mathrm{~g}$ protein) can be considered limiting amino acids due to their low content.

Grub worm is a considerable source of fat (26.3\%DM). Table 3 shows that the major saturated fatty acids found are palmitic (4.2\% of fat content) and stearic acid (8.6\% fat content). Unsaturated fatty acids are oleic acids (7.52\%), palmitoleic $(6.9 \%)$, linoleic $(12.6 \%)$ and linolenic $(11.3 \%)$.

Mineral element composition of a given food is expected to meet the recommended dietary allowance (RDA) of the consumer. The Mineral element composition of grub worms is presented in table 4 . Macroelements $\mathrm{Na}, \mathrm{K}, \mathrm{Mg}, \mathrm{Ca}, \mathrm{S}, \mathrm{P}$ and trace elements $\mathrm{Zn}, \mathrm{Fe}, \mathrm{Cu} \mathrm{Mn}$, Se were found to be present in grub worms, which when consumed or included in diet, will contribute substantially in meeting the RDA for these mineral elements.

\section{DISCUSSION}

The growing global population inevitably places continuous pressure on crop production, degradation of natural resources (FAO 2009a) and climate change set to compound the problem of food production, food and nutritional insecurity on a sustainable basis. Global efforts are geared towards providing more ecologically sound foods (FAO 2013).Insects, worms and larval stage of insects are a healthy, nutritious and tasty alternative, and they constitute a source of higher quality protein for humans than we can obtain from plants.

Insects, insect larvae, caterpillars and worms that sometimes infest farm crops and other vegetation have been found to have high content and high value nutrients comparable to animal source foods. On top of the amount of protein, fats, antioxidants, vitamins and minerals provided, insects are more digestible than other protein sources; edible insects are eaten whole and this adds a myriad of other nutritional benefits; body can absorb more of what is available and have therefore been recommended by many researchers as good sources of protein, minerals, vitamins and energy (Solomon, M., \& Prisca, N. 2012; Xiaoming, C. et al., 2010; \& Ladeji, O. et al., 2003). Nutritive value depends on several factors: protein content, which varies widely among foods; protein quality, which depends on the kinds of amino acids present (both essential and non essential), and whether the quality complies with human needs; and protein digestibility.

The grub worms are wide spread in plant and animal dungs almost all year round, can be easily propagated and are environmentally friendly. In this study, grub worms from cattle dungs were analyzed for their nutrient contents. The worms contain high protein content $(49.2 \%)$ and all the essential and non essential amino acids were detected. Grub worm can be considered a good source of protein of high biological value because of its complete amino acid profile, and when consumed or used to supplement tuber, cereal, legume-based feeds, can compensate for limiting amino acids such as lysine, tryptophan and threonine which are deficient in certain cereals and legumes. Nutritional intake of such a diet can therefore be considered balanced, and can support growth, development and repairs. This is particularly important in underdeveloped countries where protein- energy malnutrition is common among children. Elemo et al., (2011) and Nirmala, I. R., \& Pramono, M. S. (2017) have reported similar nutrient potentials and benefits of Sago worms. In a research that evaluated the protein content of species from a number of insect orders shows protein content range between 13-77\% dry matter (Xiaoming, C. et al., 2010). In order to make further recommendations for the use of protein of grub worms, it is important to determine the digestibility of the protein.

Edible worms and caterpillars contain an average of $10-60 \%$ fat dry matter depending on the developmental stage. The fat is present in several forms in the insect ranging from triglycerols, phospholipids, saturated and unsaturated fatty acids depending on the source of food which the larvae feeds upon. Edible insects and worms have been reported to be good sources of unsaturated fats. Essential fatty acids cannot be synthesized by the human body and must be obtained through diet. Insect are a great way to deliver these healthy fats. Crickets, for example, have a perfect Omega 3:6 balance. Grub worm contains both saturated and PUFAs. Fats are energy reserves, structural components and precursors for the synthesis of other body molecules such as some vitamins and hormones. Lipid of grub worms can therefore supply precursors for synthesis of body components.

In this study, the grub worm was found to contain wide range of mineral elements. This agrees with the findings of other researchers $(6,10,11,15]$ who reported the presence of similar mineral elements profile in Sago worm, mopine worms, giant mealworm, palm weevil larvae and giant grasshoppers. Mineral elements are important cofactors and structural components in the body. Grub worms can be good sources of mineral elements to support body functions.

It is concluded that Grub worms are nutritionally rich sources of essential micro- and Macronutrients. They can be included among common snacks and as nutritional supplement or functional food for intended high nutrient-dense special diets. Economically, grub worms can be cultivated on a large scale using animal dungs or compost dungs, requiring 
Table 1: Proximate Nutrient Composition of Varies coleoptera(Grub worms)(g/100g DM)

\begin{tabular}{lc}
\hline Moisture & $7.05 \pm 2.11$ \\
Crude Protein & $49.16 \pm 0.13$ \\
Crude Fat & $26.34 \pm 1.02$ \\
Crude Fiber & $2.09 \pm 0.12$ \\
NFE & $19.02 \pm 1.00$ \\
Ash & $5.48 \pm 1.22$ \\
Energy $($ Kcal $)$ & $509.78 \pm 12.3$ \\
\multicolumn{1}{c}{ Table 2: Mineral Element Composition of Varies coleoptera $($ Grub worms) (mg/100) } \\
Selenium & $2.79 \pm 0.34$ \\
Phosphorus & $6.58 \pm 1.08$ \\
Sulphur & $5.48 \pm 1.03$ \\
Calcium & $7.06 \pm 0.86$ \\
Potassium & $6.23 \pm 0.45$ \\
Sodium & $30.14 \pm 2.11$ \\
Magnesium & $12.01 \pm 1.76$ \\
Manganese & $1.44 \pm 0.7$ \\
Iron & $4.07 \pm 1.23$ \\
Zinc & $3.31 \pm 0.67$ \\
Copper & $0.15 \pm 1.03$ \\
\hline
\end{tabular}

Table 3: Amino Acid Profile of Grub worms (g/100g protein)

\section{Non-Essential}

\section{Alanine}

Aspartic acid

Glutamic acid

Glycine

Proline

Cystein

Serine

Tyrosine

8.3

Arginine

Histidine

\section{Essential}

\section{Isoleucine}

Leucine

Lysine

Methionine

Table 4: Some Fatty Acids of Grub Worms (\% lipid content)

\begin{tabular}{|c|c|c|}
\hline \multirow[t]{2}{*}{ SFA } & Palmitic acid & $\begin{array}{l}1.2 \\
8.6\end{array}$ \\
\hline & Stearic acid & 8.6 \\
\hline \multirow[t]{3}{*}{ PUFA } & Oleic acid & 7.5 \\
\hline & Linoleic acid & 12.6 \\
\hline & Linolenic acid & 10.3 \\
\hline
\end{tabular}




\section{REFERENCES}

1. Alhassan, A. J., Sule, M. S., Hsassan, J. A., Baba, B. A., Aliyu, A., \& Aliyu, M. D. (2009). Proximate and elemental composition of white grubs. Bayero Journal of Pure and Applied Sciences, 2(2), 188190.

2. AOAC. (2015). Official Methods of Analysis $20^{\text {th }}$ edn. Association of Official Analytical Chemists. Washington DC 2015.

3. Ayieko, M.A., \& Oriaro, V. (2008) Consumption, Indigenous Knowledge and Cultural Values of the Lakefly Species Within the Lake Victoria Region. Africa J. Env. Sc. and Tech. 2(10), 282-286.

4. Bednarova, M. (2013). Possibilities of Using Insects as Food in the Czech Republic Dissertation Thesis Mendel University, Brno.pp 50-92

5. Elemo, B. O., Elemo, G. N., Makinde, M. A., \& Erukainure, O. L. (2011). Chemical evaluation of African palm weevil, Rhychophorus phoenicis, larvae as a food source. Journal of Insect Science, 11(1), 146. http://doi.org/10.1673/031.011.14601

6. Finke, M.D., \& Oonincx, D.D. (2014). Insects as Food for Insectivores In: J Merales-Ramos, G Rojas, DI Shapiro-Ilan(Eds) Mass Production of Beneficial Organisms:Invertebrates and Entomopathogens. Elsevier, New York. 583-616.

7. Food and Agricultural Organization (FAO) (2013). Edible Insects: Future Prospects for Food and Feed Security. Rome, Italy. http://www.fao.org/docrep/018/i3253e06

8. Food and Agricultural Organization (FAO). (2009a). How to Feed the World in 2050. Paper Presented at the High Level Expert Forum, Rome, Italy, 12-13 0ctober.

9. Food and Agricultural Organization. (FAO). (2009b). Biodiversity and Nutrition, a Common Path. Rome.

10. Forbes-Ewan, C. (2013). Lcky Insects are Tasty Treats that are good. Defence Science Technology Organization. https://theconversation.com
11. Kourimskaa, L., \& Adamkovab, A. (2016) Nutritional and Sensory Quality of Edible Insects. Nutrition and Food Science J. 4, 22-26.

12. Ladeji, O., Solomon, M., \& Maduka, H. (2003). Proximate chemical analysis of Zonocerus variegatus (Giant grasshopper). Nigerian Journal of Biotechnology, 14(1), 42-45.

13. Nirmala, I. R., \& Pramono, M. S. (2017). Sago worms as a nutritious traditional and alternative food for rural children in Southeast Sulawesi, Indonesia. Asia Pacific Journal of Clinical Nutrition, 26(Supplement), S40-S49

14. Okpala B. (2016). Why Sago Worms are Essential. Global Food Book. https://globalfoodbook.com

15. Rumpold, B. A., \& Schlüter, O. K. (2013). Nutritional Composition and Safety Aspects of Edible Insects. Mol. Nutr. Food Res. 57, 50-92.

16. Solomon, M., \& Prisca, N. (2012). Nutritive value of Lepidoptara litoralia (edible caterpillar) found in Jos Nigeria: implication for food security and poverty alleviation. African Journal of Food, Agriculture, Nutrition and Development, 12(6), 6737-6747.

17. Van Huis, A., Van Itterbeeck, J., Klunder, H., Mertens, E., Halloran, A., Muir, G., \& Vantomme, P. (2013). Edible Insects: : Future Prospects for Food and Feed Security. FAO, Rome, Italy. pp 201.

18. Xiaoming, C., Ying, F., Hong, Z. (2010). Review of the Nutritive Value of Edible Insects. Edible Insects and other Invertebrates I Australia: Future Prospects. Proceedings of a Workshop on AsiaPacific Resources and their Potential for Development, 19-21 February 2008, Bangkok 142157.

19. Yen, A., Bilney, C., Shackleton, M., \& Lawler, S. (2018). Current issues involved with the identification and nutritional value of wood grubs consumed by Australian Aborigines. Insect science, 25(2), 199-210. 